BBA $662 \mathrm{I} 4$

\title{
FRUCTOKINASE FROM RAT LIVER
}

\section{PURIFICATION AND PROPERTIES}

JORGE J. SÁNCHEZ*, NÉLIDA S. GONZÁLEZ AND HORACIO G. PONTIS **

Instituto de Investigaciones Bioquimicas, Fundación Campomar, Obligado 249o, Buenos Aires, and Facultad de Ciencias Exactas y Naturales, Obligado 249o, Buenos Aires (28) (Argentina)

(Received July I5th, 1970)

\section{SUMMARY}

Fructokinase (ATP:D-fructose-I-phosphate transferase, EC 2.7.I.3) from rat liver has been purified 400 -fold. The purification procedure involves an acid treatment, a heat step at $65^{\circ},\left(\mathrm{NH}_{4}\right)_{2} \mathrm{SO}_{4}$ fractionation, chromatography on Sephadex $\mathrm{G}$-IOO and finally $\left(\mathrm{NH}_{4}\right)_{2} \mathrm{SO}_{4}$ extraction.

The enzyme appears nearly homogeneous by density gradient centrifugation but gives a single peak in sedimentation velocity analysis. Purified liver fructokinase has a $K_{m}$ of $0.46-0.80 \mathrm{mM}$ for fructose and I.56-I.33 mM for MgATP at a $\mathrm{K}^{+}$concentration of 0.4 and $0.1 \mathrm{M}$, respectively. The enzyme also phosphorylates L-sorbose and D-tagatose. No difference could be found in the phosphorylation of the pyranose and furanose forms of fructose. The enzyme is inhibited by $p$-chloromercuribenzoate and is stable up to $5{ }^{\circ}-55^{\circ}$.

\section{INTRODUCTION}

Numerous biochemical and physiological investigations $\mathbf{1}^{\mathbf{1 - 2 4}}$ clearly indicate that fructose I-phosphate is the sole initial product of the hepatic utilization of fructose. The phosphorylation of fructose is catalyzed by fructokinase (ATP:Dfructose I-phosphate transferase, EC 2.7.I.3). This cnzyme presents an interesting behaviour that distinguishes it from other hexokinases as it shows an absolute requirement for $\mathrm{K}^{+}$(ref. 7). It is also strongly and noncompetitively inhibited by one of the reaction products, $\mathrm{ADP}^{7}$. The present study was undertaken to obtain information concerning these problems. Furthermore, although fructokinase has been purified by various methods $s^{5,7,10,18}$, little is known about the chemical properties of the enzyme. This paper reports a method for the purification of fructokinase from rat liver to near homogeneity as well as some chemical properties of the protein.

* The material in this paper is taken in partial fulfillment of the requirements for the degree of Doctor in Biochemistry, Córdoba University. Present address: Departamento de Biología, Fundación Bariloche, Casilla de Correo 138, San Carlos de Bariloche, Argentina.

${ }_{\star *}$ Present address: Departamento de Biología, Fundación Bariloche, Casilla de Correo I 38 , San Carlos de Bariloche, Argentina. 
MATERIALS AND METHODS

\section{Chemicals}

Fructose, ATP (disodium salt), and creatine kinase were purchased from Sigma Chemical Company; lysozyme 3 times crystallized from Mann Research Laboratories; and Sephadex G-Ioo from Pharmacia Fine Chemicals. $\left(\mathrm{NH}_{4}\right)_{2} \mathrm{SO}_{4}$ was recrystallized from EDTA according to the method of SUTHERLAND AND WoLISAT ${ }^{25}$.

\section{Analytical techniques}

Fructose was determined by the thiobarbituric acid method according to the method of PERcheron ${ }^{26}$ in a total volume of $\mathrm{I} .2 \mathrm{ml}$. Protein was estimated according to the procedures Lowry et al. ${ }^{27}$ and WARBURG AND CHRISTIAN ${ }^{28}$ (in connection with gel filtration). Measurement of protein in fractions of the sucrose gradient was determined also by the method of MURPHY AND KIEs ${ }^{29}$.

\section{Enzyme assays}

Assay a. A colorimetric assay was based on the measurement of the fructose disappearance with a similar test as the one described by HERS ${ }^{5}$. The standard incubation mixture was as follows: $0.25 \mu$ mole of fructose, $0.3 \mu$ mole of ATP, $5 \mu$ moles of Tris buffer $\left(\mathrm{pH} 7.4\right.$ ), $25 \mu$ moles of $\mathrm{KCl}, 0.3 \mu$ mole of $\mathrm{MgCl}_{2}, 0.375 \mu$ mole of creatine phosphatc, I $\mu \mathrm{g}$ of creatine kinase, and enzyme in a total volume of $0.05 \mathrm{ml}$. Incubation was carried out for $\mathrm{I}_{5} \mathrm{~min}$ at $37^{\circ}$ and the reaction was stopped by adding $5^{\circ} \mu \mathrm{l}$ of $0 . \mathrm{I}_{5} \mathrm{M} \mathrm{ZnSO}_{4}$ and $50 \mu \mathrm{l}$ of $0 . \mathrm{I}_{5} \mathrm{M} \mathrm{Ba}(\mathrm{OH})_{2}$. After centrifugation, aliquots of the supernatant were used for the thiobarbituric acid reaction. An incubation mixture to which ATP was added after stopping the reaction by adding $\mathrm{ZnSO}_{4}$, was used as a blank.

Fructokinase activity was also measured by coupling the formation of ADP with phosphoenolpyruvate and pyruvate kinase. The pyruvate formed was estimated either colorimetrically with 2,1-dinitrophenylhydrazine or spectrophotometrically with lactate dehydrogenase.

Assay $b$. A standard incubation mixture was as follows: $0.25 \mu$ mole of fructose, $0.3 \mu$ mole of ATP, $5 \mu$ moles of Tris buffer (pH 7.4), $25 \mu$ moles of $\mathrm{KCl}, 0.3 \mu$ mole of $\mathrm{MgCl}_{2}, 0.25 \mu$ mole of phosphoenolpyruvate, $3 \mu \mathrm{l}$ of pyruvate kinase, and enzyme in a total volume of $0.05 \mathrm{ml}$. Incubation was carried out for $15 \mathrm{~min}$ at $37^{\circ}$ and the reaction was stopped by heating the tubes for I min at $100^{\circ}$. After cooling, Io $\mu \mathrm{l}$ of a mixture of NADH (o.I $\mu$ mole) and lactate dehydrogenase ( $\mathrm{N} \mu \mathrm{g}$ ) were added, followed by a second incubation for $5 \mathrm{~min}$ at $37^{\circ}$. Water was added to $0.5 \mathrm{ml}$ and the change in absorbance at $340 \mathrm{~nm}$ was followed in Beckman DU spectrophotometer. A blank without fructose was used as reference.

This assay is not suitable to measure enzyme activity in the first fractions of the purification procedure, as the addition of ATP alone causes a rapid ADP formation (presumably due either to ATPase or adenylate kinase which might be inactivatcd during the heat treatment).

Assay c. The standard incubation mixture was as for Assay b, but the reaction was stopped by adding $80 \mu \mathrm{l}$ of $10 \%$ trichloroacetic acid, followed by $0.15 \mathrm{ml}$ of $2,4^{-}$ dinitrophenylhydrazine (0. $\%$ in $2 \mathrm{M} \mathrm{HCl}$ ). After 5 min at $37^{\circ}, 0.4 \mathrm{ml}$ of $2.5 \mathrm{M} \mathrm{NaOH}$ 
was added, and the tubes were mixed and centrifuged. The absorbance of the supernatant at $520 \mathrm{~nm}$ was measured.

\section{Unit}

One unit of fructokinase is defined as the amount of enzyme that will catalyze the disappearance of I $\mu$ mole of fructose or the formation of I $\mu$ mole of ADP or fructose I-phosphate per min at $37^{\circ}$.

\section{Gel filtration}

Sephadex G-Ioo was prepared by swelling in distilled water on a boiling-water bath for $I \mathrm{~h}$. The gel suspension was allowed to cool down and settle. The supernatant was poured out, removing small particles. The cleaning cycle was repeated until the supernatant was cleared. Usually it was sufficient to perform the operation twice.

\section{Sucrose gradient centrifugation}

Sucrose gradients were $5-20 \%(\mathrm{w} / \mathrm{v})$ in $0.05 \mathrm{M}$ Tris buffer $(\mathrm{pH} 7.4)$ prepared by the method of MARTIN AND AMEs ${ }^{30}$. The gradients had a volume of $4.6 \mathrm{ml}$. A $30-\mu \mathrm{l}$ sample $(200 \mu \mathrm{g}$ protein) was layered on top. After running for $5 \mathrm{~h}$ at 40000 $\mathrm{rev} . / \mathrm{min}$ in a SW-50 rotor in a Spinco Model L, the rotor was allowed to coast to a stop. Fractions of $I_{50} \mu \mathrm{l}$ were collected. As sedimentation control lysozyme was used. Lysozyme activity was measured in a mixture containing $3 \mathrm{mg}$ of Bacillus stearothermophilus I503-4R (ref. 3I), $5 \mu$ l of o.I M EDTA ( $\mathrm{pH} 7$ ), $60 \mu$ l of o.oI M Tris buffer ( $\mathrm{pH}_{7.5}$ ), and $\mathrm{I} 5 \mu \mathrm{l}$ of each gradient fraction. Incubation was carried out for I5 $\mathrm{min}$ at $20^{\circ}$, and the absorbance at $520 \mathrm{~nm}$ was measured.

\section{Disc gel electrophoresis}

Electrophoresis of the enzyme was carried out in polyacrylamide gel ( $\mathrm{pH} 8.9$ ) by the method of ORNSTEIN AND DAvis ${ }^{32,39}$. The degree of polymerization of the gel was $7.5 \%$; it was stained for proteins with I\% Amido Schwarz in $7 \%$ acetic acid for $30 \mathrm{~min}$ and washed continously with $7 \%$ acetic acid for $24-36 \mathrm{~h}$ or run through electrophoresis. Runs were performed at $4^{\circ}$ for $2 \mathrm{~h}$ with $5 \mathrm{~mA}$ per tube. Fructokinase activity in the gel was measured after electrophoresis by cutting the gel cylinder longitudinally. One-half was used for staining. The other half was divided in 2 -mm thick sections. Enzyme activity was tested with each section according to Assay a.

\section{Analytical ultracentrifugation}

Ultracentrifuge studies were done in a Spinco Model E analytical ultracentrifuge. Analyses were performed with the enzyme dissolved in o.or $\mathrm{M}$ Tris buffer $(\mathrm{pH}$ 7.5). Runs were for $214 \mathrm{~min}$ at $42000 \mathrm{rev} . / \mathrm{min}$ and at $7^{\circ}$.

The sedimentation constant of the protein was calculated according to the procedure of ScHaCHMAN ${ }^{36}$.

\section{Conformation studies}

Differently prepared solutions of fructose were used in these studies. Sulution a was a $50 \mathrm{mM}$ fructose solution prepared $24 \mathrm{~h}$ before use; this solution corresponds to an equilibrium mixture of the pyranose and furanose forms. Solution b was prepared by dissolving, just before incubation started, the amount of crystalline fructose 
(pyranose) necessary to make a $50 \mathrm{mM}$ solution. The time lapse between the addition of water to dissolve the fructose and the start of incubation was approx. $15 \mathrm{sec}$.

Activity determinations with both fructose solutions were carried out under the condition of Assay $b$ except that the incubation times were as follows: $0.5, \mathrm{I}$, I.5, 2, 4, and $6 \mathrm{~min}$ (Fig. 7). The ADP formed in the reaction was estimated as described in Assay b after stopping the reaction by heating the tubes for $1 \mathrm{~min}$ at $100^{\circ}$.

RESULTS

\section{Purification of fructokinase}

Wistar rats weighing I50-200 g were decapitated and allowed to bleed. Livers were removed, sliced and chilled in ice. The slices were freed of fat tissue and repeatedly washed in ice-water to remove blood. Liver slices were then weighed and homogenized with 3 volumes of icc-cold o. $5 \mathrm{M} \mathrm{KCl}$ in a Waring blender for $3 \mathrm{~min}$. All the following steps in the purification procedure were carried out at $0-4^{\circ}$. The homogenate was centrifuged for $\mathrm{I}_{5} \mathrm{~min}$ at $20000 \times g$ in a Sorvall refrigerated centrifuge. The supernatant (crude extract) was adjusted to $\mathrm{pH} 5$ by addition of $\mathrm{x}$ M acetic acid with constant stirring. The acid extract was then centrifuged for $15 \mathrm{~min}$ at $20000 \times \mathrm{g}$.

The acid supernatant was heated in a water bath $\left(85^{\circ}\right)$ under constant stirring. When the temperature had reached $65 \pm 1^{\circ}$, the enzyme solution became cloudy and was heated for a further period of $2 \mathrm{~min}$ at this temperature. The solution was then cooled immediately in an ice-bath until its temperature reached $4^{\circ}$. This took approx. 2-3 min. Attempts to perform the acid purification and heat treatment in one step resulted in loss of enzyme activity.

The cold enzyme solution was clarified by passing it through a layer of cheesecloth to remove the denatured proteins or by centrifuging it for $\mathrm{I}_{5} \mathrm{~min}$ at $20000 \times g$. The filtrate was mixed with one-twentieth its volume of I M acetate buffer ( $\mathrm{pH}$ 5.o). Solid $\left(\mathrm{NH}_{4}\right)_{2} \mathrm{SO}_{4}$ was added very slowly to bring the solution to $45 \%$ saturation.

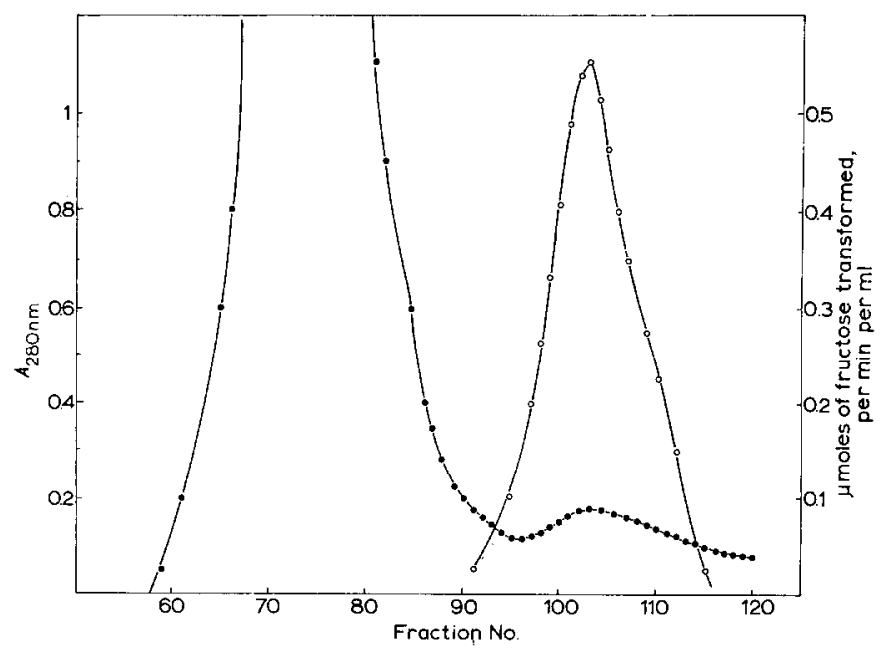

Fig. I. Sephadex G-Ioo chromatography. For details see text. - absorbance at $80 \mathrm{~nm}$ (protein); $\mathrm{O}-\mathrm{O}$, enzyme activity determined by Assay a in aliquots of $25 \mu \mathrm{l}$.

Biochim. Biophys. Acta, 227 (I97I) 67-78 
After 30 min stirring, the precipitate was collected by centrifugation for $\mathbf{5}$ min at $20000 \times g$ and dissolved in ice-cold water. The solution was dialyzed for $3 \mathrm{~h}$ against 500 vol. of $0.01 \mathrm{M}$ Tris buffer $\left(\mathrm{pH}_{7.5}\right)$. The dialysis step could be omitted without modifying the purification obtained by gel filtration.

I ml of enzyme solution (50 $\mathrm{mg}$ protein) was applied to a $2 \mathrm{~cm} \times 80 \mathrm{~cm}$ column of Sephadex G-Ioo previously equilibrated overnight with o.or M Tris buffer ( $\mathrm{pH}$ 7.5). The column was eluted with the same buffer, collecting I-ml fractions at a flow rate of $0.2 \mathrm{ml} / \mathrm{min}$. The fractions containing fructokinase activity (Fig. I) were pooled and freeze-dried to about one-hundredth volume of the homogenate. The concentrated preparation was then dialyzed overnight against o.or $\mathrm{M}$ Tris buffer ( $\mathrm{pH} 7.5$ ). $\left(\mathrm{NH}_{4}\right)_{2} \mathrm{SO}_{4}$ solution (saturated at room temperature, $\mathrm{pH} 6.8$ ) was added to the dialysate to bring the enzyme solution to $70 \%$ saturation. After standing for $30 \mathrm{~min}$, the precipitate was collected by centrifugation for $20 \mathrm{~min}$ at $20000 \times \mathrm{g}$. The precipitate was extracted twice with $0.4 \mathrm{ml}$ of 70,50 , and $30 \%$ saturated $\left(\mathrm{NH}_{4}\right)_{2} \mathrm{SO}_{4}$, successively. In each case the remaining precipitate was centrifuged for $20 \mathrm{~min}$ at $20000 \times \mathrm{g}$. The last two extractions with $30 \%\left(\mathrm{NH}_{4}\right)_{2} \mathrm{SO}_{4}$ contained the fructokinase activity.

The enzyme was purified $250-400$-fold over the initial homogenate with an overall yield of $30 \%$. Typical data of a purification are shown in Table I.

\section{TABLE I}

PURIFICATION OF FRUCTOKINASE

\begin{tabular}{|c|c|c|c|c|c|c|}
\hline Step & $\begin{array}{l}\text { Vol. } \\
(m l)\end{array}$ & Units & $\begin{array}{l}\text { Protein } \\
(m g / m l)\end{array}$ & $\begin{array}{l}\text { Specific } \\
\text { activity } \\
\text { (units/mg) }\end{array}$ & $\begin{array}{l}\text { Purifi- } \\
\text { cation }\end{array}$ & $\begin{array}{l}\text { Yield } \\
(\%)\end{array}$ \\
\hline Homogenate & I 34 & 0.868 & 56 & 0.015 & $\mathbf{I}$ & IOO \\
\hline Crude extract & IOO & I.I7 & 40 & 0.029 & I.9 & IOO \\
\hline pH 5 supernatant & $7^{8}$ & 1.20 & 22 & 0.055 & $3 \cdot 7$ & 80 \\
\hline Heat supernatant & 69 & 1.02 & 7 & 0.146 & 9.7 & $6 \mathrm{I}$ \\
\hline $\mathrm{O}-45 \%\left(\mathrm{NH}_{4}\right)_{2} \mathrm{SO}_{4}$ & I. 5 & $35 \cdot 7$ & IO5 & 0.340 & 22.6 & 47 \\
\hline Sephadex G-I oo eluate & 75 & 0.57 & 0.20 & 2.85 & I90 & 37 \\
\hline $30 \%\left(\mathrm{NH}_{4}\right)_{2} \mathrm{SO}_{4}$ extraction & $\mathbf{I}$ & $34 \cdot 4$ & 6.14 & 5.6 & $37^{\circ}$ & $3^{\circ}$ \\
\hline
\end{tabular}

\section{Criteria of purity}

Sucrose gradient centrifugation. The profile of the enzyme is depicted in Fig. 2. A single absorption peak calculated by the difference between the absorbances at 2I5 and $225 \mathrm{~nm}$ (ref. 29), closely fitting the fructokinase activity, was observed. The profile or the position of the peak was not affected by $0.25 \mathrm{M} \mathrm{KCl}$ and $0.04 \mathrm{M}$ mercaptoethanol. The sedimentation coefficient with lysozyme as a standard was found to be 2.85 (ref. 30).

Ultracentrifugal pattern. The sedimentation pattern of the enzyme preparation is shown in Fig. 3. The boundary of the purified enzyme moved as a single symmetrical peak with a sedimentation constant of $s_{20, w}=2.95 \mathrm{~S}$.

Disc gel electrophoresis. When the purified enzyme preparation was subjected to electrophoresis in polyacrylamide gel at $\mathrm{pH} 8.9$, two bands of protein migrating towards the cathode were observed. Both bands, as can be seen in Fig. 4, overlap with the enzyme activity detected in gel slices as described under MATERIALS AND METHODS. 


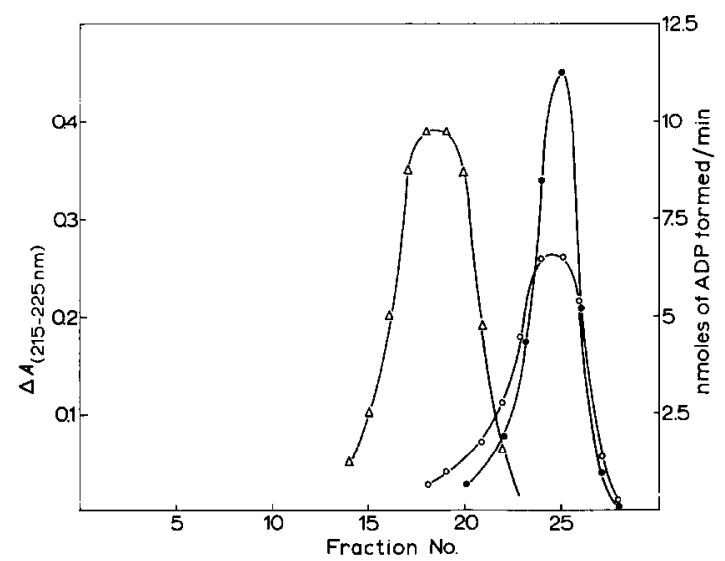

Fig. 2. Sucrose density gradient centrifugation. For details see text. $\bigcirc-O$, difference between absorbances at $2 \mathrm{I} 5$ and $225 \mathrm{~nm}$ (protein); $\triangle-\triangle$, lysozyme activity; -0 , fructokinase activity (Assay c).

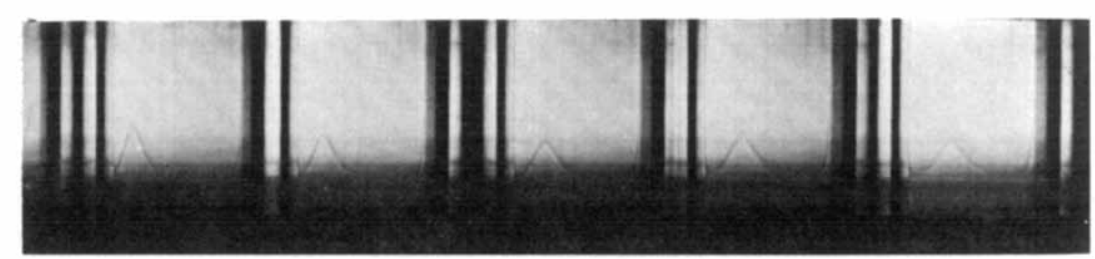

Fig. 3. Sedimentation velocity pattern of fructokinase ( $12 \mathrm{mg} / \mathrm{ml}$ ) in o.oI M Tris buffer ( $\mathrm{pH} 7 \cdot 5)$. The photographs were taken at $99, \mathrm{I} 29, \mathrm{I} 86$, and $2 \mathrm{I}_{4} \mathrm{~min}$ after speed of $42 \mathrm{O}_{1} 0 \mathrm{rev} / \mathrm{min}$ was reached. Direction of sedimentation is from left to right.

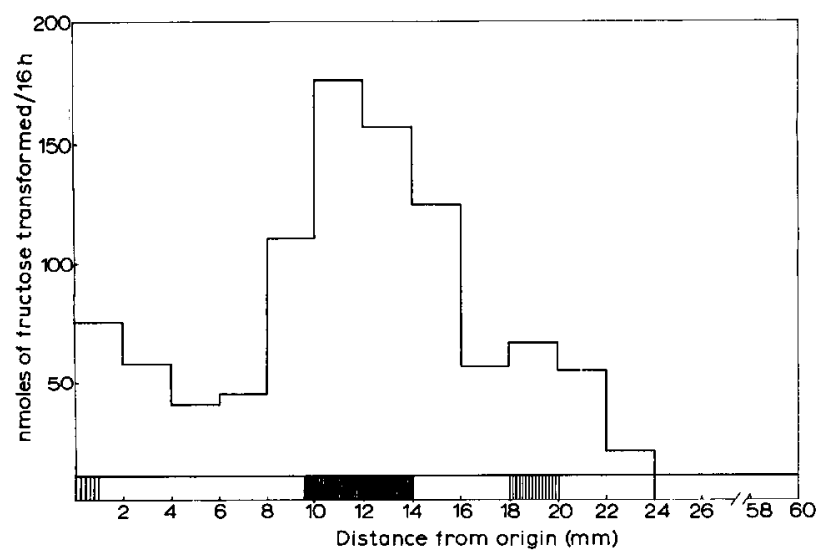

Fig. 4. Polyacrylamide gel electrophoresis of fructokinase. For details see text. The intensity of the hatched areas corresponds to the colour developed with Amido Scliwarz.

Biochim. Biophys. Acta, 227 (1971) 67-78 


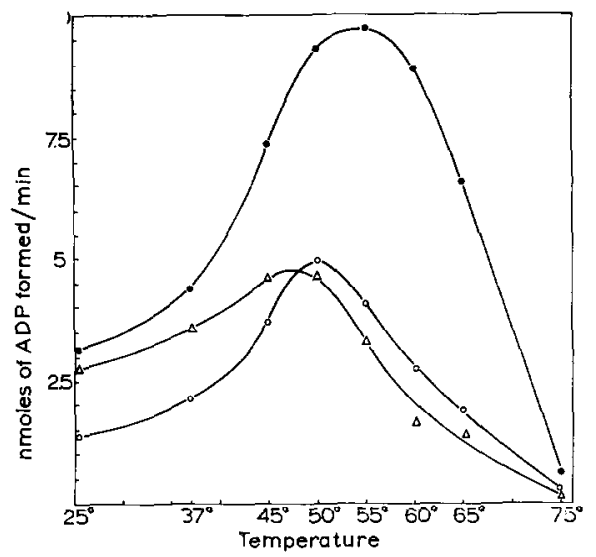

Fig. 5. Effect of temperature on fructokinase. Activity (Assay a) with different substrates:
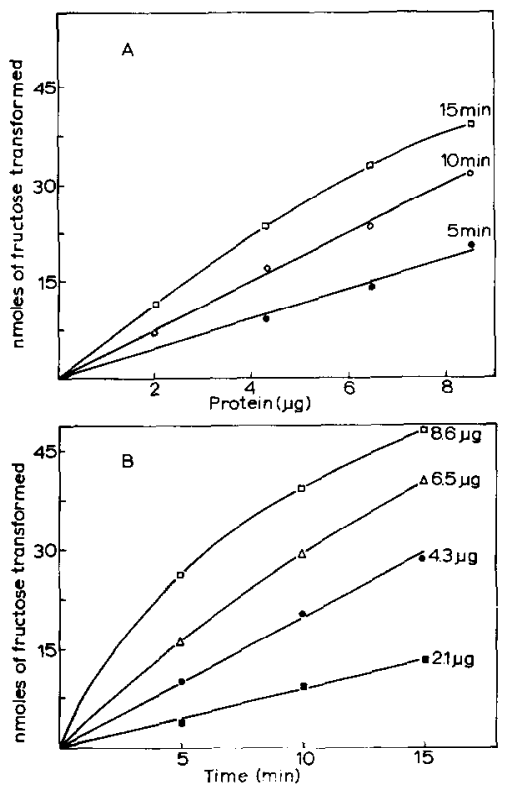

- fructose; $O-O$, sorbose; $\triangle-\Delta$, tagatose.

Fig. 6. Protein concentration (A) and tissue curves (B) of fructokinase reaction. Assay a. Similar curves can be obtained with Assays $b$ and $c$. In all cases incubations were carried out in the absence of ATP-regenerating system.

\section{Properties of enzyme}

Stability. No loss of activity occurs upon storage of the purified enzyme in $30 \%$ saturated $\left(\mathrm{NH}_{4}\right)_{2} \mathrm{SO}_{4}$ or in o.or M Tris buffer $(\mathrm{pH} 7.4)$ at $-\mathrm{I}^{\circ}$ for at least 7 months.

When fructokinase activity was tested as a function of temperature, the enzyme was stable up to $50-55^{\circ}$ and then decreased. A similar behaviour was found out with other ketoses also phosphorylated by fructokinase, as can be seen in Fig. 5. From these data the energy of activation for the phosphorylation of fructose was calculated as II kcal per mole and a $Q_{10}$ of about 2. A similar value was obtained for sorbose.

Kinetics. The broad $\mathrm{pH}$ optimum already reported ${ }^{5}$ was also found for the

\section{TABLE II}

Michaelis CONSTANTS FOR FRUCTOSE AND MgATP at Different $\mathrm{K}^{+}$concentrations

The Michaelis constants were determined by Assay a and by Assay d. See subsequent paper ${ }^{37}$.

\begin{tabular}{|c|c|c|c|}
\hline Substrate & $\begin{array}{l}\text { Concn. } \\
(m M)\end{array}$ & $\begin{array}{l}K^{+} \\
(M)\end{array}$ & $\begin{array}{l}K_{m} \\
(m M)\end{array}$ \\
\hline Fructose & $\begin{array}{l}0.5-10 \\
0.5-10\end{array}$ & $\begin{array}{l}0.4 \\
0.1\end{array}$ & $\begin{array}{l}0.46 \\
0.8\end{array}$ \\
\hline $\begin{array}{l}\text { MgATP } \\
\quad(\text { Ratio ATP/Mg2+ }=I)\end{array}$ & $\begin{array}{l}0.5-10 \\
0.5-10\end{array}$ & $\begin{array}{l}0.4 \\
0.1\end{array}$ & $\begin{array}{l}\mathrm{T} .56 \\
\mathrm{I} .33\end{array}$ \\
\hline
\end{tabular}


TABLE III

SUBSTRATE SPECIFICITY OF FRUCTOKINASE AT DIFFERENT K+ CONCENTRATIONS

Fructokinase activity (Assay a) towards the various substrates referred to activity with fructosc at $0.15 \mathrm{M} \mathrm{K}+$ as unity.

\begin{tabular}{lll}
\hline $\begin{array}{l}\text { Ketose } \\
(4 \mathrm{mM})\end{array}$ & $\begin{array}{l}0.15 \mathrm{M} \\
\mathrm{K}^{+}\end{array}$ & $\begin{array}{l}0.5 \mathrm{M} \\
\mathrm{K}^{+}\end{array}$ \\
\hline & & \\
D-Fructose & $\mathrm{I}$ & $\mathrm{I} .35$ \\
L-Sorbose & 0.15 & $\mathrm{I.03}$ \\
D-Tagatose & 0.69 & 0.86 \\
\hline
\end{tabular}

purified enzyme. A higher activity was found with Tris buffer as compared with phosphate or acetate-borate-cacodilate buffers. With Tris buffer, enzyme activity presented a plateau at $\mathrm{pH} 7.2-8.5$.

As shown in Fig. 6, proportionality between fructose transformed and enzyme concentration or time only held when the reaction was allowed to proceed to a small extent in the absence of an ATP-regenerating system. This behaviour has been shown to be caused by inhibition of the ADP formed in the reaction?

The Michaelis constants determined for fructose and MgATP are presented in Table II for different $\mathrm{K}^{+}$concentrations. It should be noticed that an increase in $\mathrm{K}^{+}$concentration brings a diminution of the $K_{m}$ for fructose.

Substrate specificity: structure. The purified enzyme phosphorylates also Lsorbose and D-tagatose. Moreover, $\mathrm{K}^{+}$stimulation of enzymatic activity towards these sugars can be seen in Table III. However, at concentrations of $4 \mathrm{mM}$, D-tagatose and L-sorbose inhibit the phosphorylation of fructose 36 and $24 \%$, respectively, at $0.5 \mathrm{M} \mathrm{K}^{+}$. It should be mentioned here that metabolites like sorbitol, fructose 6-

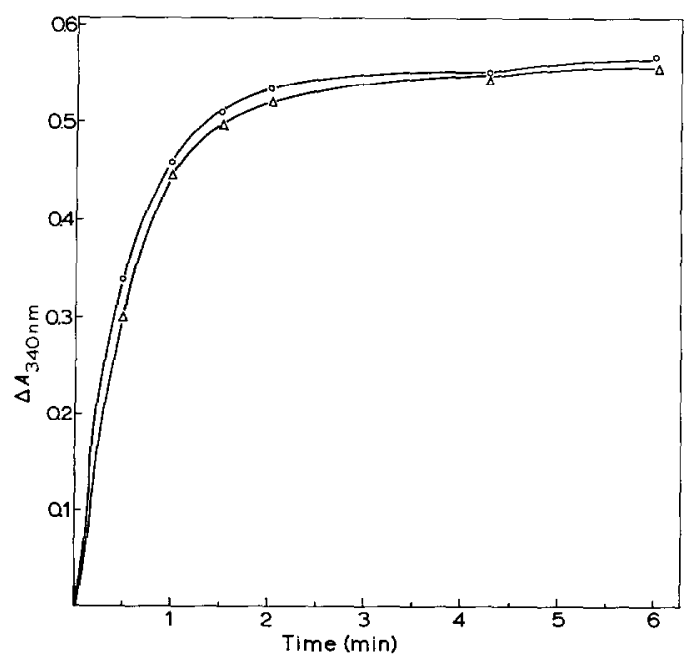

Fig. 7. Fructokinase activity towards the pyranose and furanose forms of fructose. For details see text. $\triangle-\triangle$, fructopyranose; $O-O$, equilibrium mixture of fructopyranose and fructofuranose. 


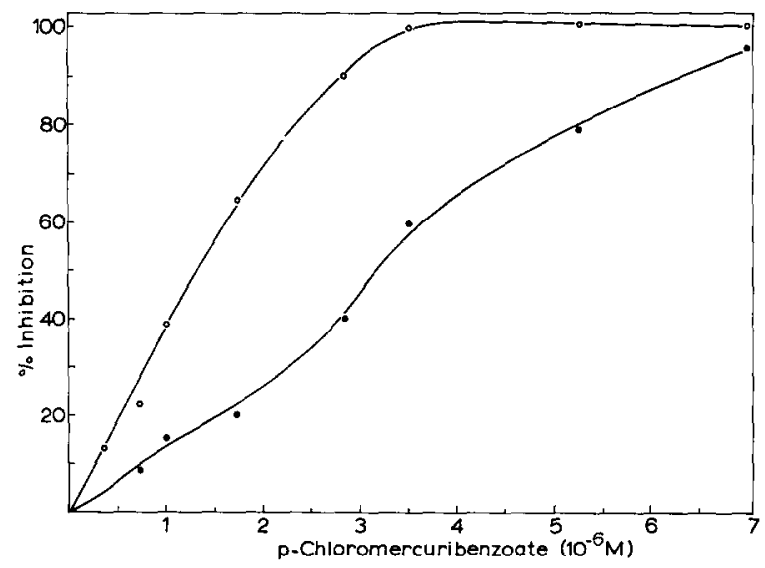

Fig. 8. Effect of $p$-chloromercuribenzoate on fructokinase. Activity (Assay a) at different temperatures. For details see text. $\mathrm{O}-\mathrm{O}, 55^{\circ} ;-0.37^{\circ}$.

phosphate, fructose I,6-diphosphate, glucose I-phosphate, dihydroxyacetone phosphate, and glyceraldehyde have no effect on the activity of fructokinase.

Substrate specificity: conformation. It can be seen in Fig. 7 that fructokinase phosphorylates at the same rate a newly prepared solution of fructose (pyranose form) and a solution of fructose where the pyranose and furanose forms were equilibrated.

Effects of thiols. It has been shown that fructokinase can be inhibited by $p$ chloromercuribenzoate ${ }^{9,10,18}$, suggesting the presence of essential sulfhydryl groups for enzyme activity. When the purified enzyme was treated with $p$-chloromercuribenzoate, it was found that $50 \%$ inhibition was attained at a concentration of $3.2 \cdot \mathrm{IO}^{-6}$ $\mathrm{M}$ at $37^{\circ}$ (see Fig. 8). However, the same $p$-chloromercuribenzoate concentration caused $100 \%$ inhibition at $55^{\circ}$. The concentration of $p$-chloromercuribenzoate which causes $100 \%$ inhibition, was found for the phosphorylation of sorbose to be $2.5 \cdot 10^{-6}$ $\mathrm{M}$ and for tagatose $\mathrm{I} .75 \cdot 1 \mathrm{O}^{-6} \mathrm{M}$.

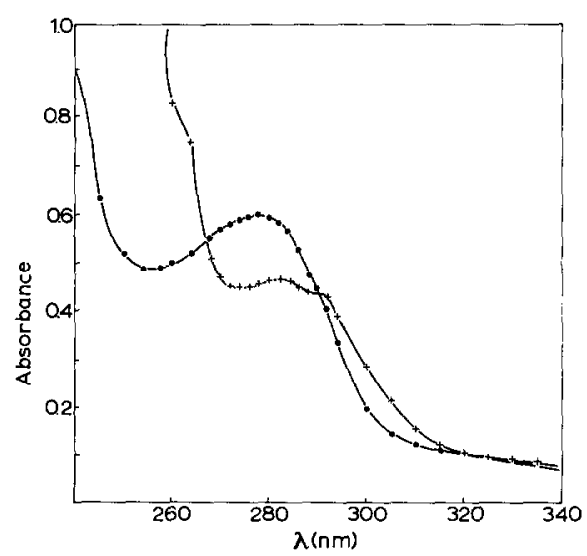

Fig. 9. Absorption spectra of fructokinase. The protein $(0.3 \mathrm{mg} / \mathrm{ml})$ was dissolved in $0.12 \mathrm{M}$ phosphate buffer $\left(\mathrm{pH}_{7}\right)(--)$ ) and was brought to $\mathrm{pH}$ i 2 with I $\mathrm{M} \mathrm{NaOH}(+-+)$. 
Molecular weight. The molecular weight determined by density gradient centrifugation using lysozyme as standard, according to the method of MARTIN AND AMEs $^{30}$, averaged 28 ooo.

Absorption spectra. In Fig. 9 are shown the ultraviolet spectra of the purified protein at both neutral and alkaline $\mathrm{pH}$. The $A_{280 \mathrm{~nm}} / A_{260} \mathrm{~nm}$ ratio was I.2. The characteristic absorption maximum at $278 \mathrm{~nm}$ contributed by aromatic amino acid residues was seen at neutral $\mathrm{pH}$.

\section{DISCUSSION}

The purification procedure reported here for fructokinase from rat liver permits the isolation of the enzyme with a yield of about $35 \%$ by a rather small number of purification steps.

The enzyme preparation appears to be homogeneous by sedimentation velocity, but only near-homogeneous by density gradient centrifugation. By disc gel electrophoresis two protein bands were obtained. However, both proteins showed enzyme activity. The significance of this result is not clear, but it could indicate the existence of two enzyme forms. These results are approximate and require further study, but nevertheless they might have some significance.

The fructokinase is very stable under a variety of conditions, such as aging, heat inactivation and acid denaturation. The enzyme possesses sulfhydryl groups which are related to the activity, but contradictory results regarding its number are obtained with the $p$-chloromercuribenzoate experiments. Effectively, assuming a molecular weight of 30000 for the protein, the number of sulfhydryl groups calculated according to the inhibition data would be about I at $55^{\circ}$, which is not in agreement with the number obtained at $37^{\circ}$ which is about 2 . A possible explanation for the difference observed could be a change in conformation of the enzyme with increased temperature.

The $K_{m}$ values reported here for fructose $(0.46-0.8 \mathrm{mM})$ and for MgATP (I.56-I.33 mM) at $\mathrm{K}^{+}$concentrations of 0.4 and $0.14 \mathrm{M}$, respectively, are in good agreement with those previously found by ADELMAN et al..$^{18}$ and HERS ${ }^{5}$. The value for MgATP obtained by PARKs et al. ${ }^{7}$ is about ro times lower than any other teported.

We have confirmed that fructokinase catalyzes the phosphorylation of Lsorbose ${ }^{10,18}$. Also we have shown that the enzyme is active towards D-tagatose. The purity of both sugars was ascertained by paper chromatography and shown to be free of fructose. Moreover, the change of enzyme activity with temperature is very similar for D-fructose, I-sorbose, and D-tagatose. Measurement of the equilibrium of aqueous fructose solution indicates $80 \%$ pyranose, $20 \%$ furanose and considerably less than $0.1 \%$ of the open form ${ }^{33-35}$. Which of those forms is the substrate for fructokinase? The experiments reported here seem to indicate that the enzyme is unable to distinguish between the cyclic forms. Similar experiments carried out with yeast hexokinase $^{38}$ show that this enzyme phosphorylates $\beta$-D-fructofuranose. Our method of measure docs not permit to detect if the open form would have becn phosphorylated more specifically. In other words, the question remains open if the open-chain form is preferred. 


\section{ACKNOWLEDGEMENTS}

This investigation was supported in part by Public Health Service Research Grant GM-03442 from the National Institute of Health, United States Public Health Service, by the Rockefeller Foundation, and by the Consejo Nacional de Investigaciones Cientïficas y Técnicas (Argentina).

The authors wish to express their gratitude to Dr. Luis F. Leloir for his continued interest and support of this work. They also wish to thank Dr. I. D. Algranati who kindly gave them the Bacillus stearothermophilus, and Dr. J. Dellacha who performed the analytical ultracentrifugation. They are also indebted to their colleagues at the Instituto de Investigaciones Bioquímicas for useful discussions and criticism.

J.J.S. is a Fellow of the Consejo Nacional de Investigaciones Científicas y Técnicas, Argentina.

H.G.P. is a Career Investigator of the Consejo Nacional de Investigaciones Cientificas y Técnicas, Argentina.

\section{REFERENCES}

I D. G. WALKER, Biochem. J., 87 (1963) 576.

2 D. G. Walker, Biochim. Biophys. Acta, 77 (I963) 209.

3 D. L. Di Pietro, J. Biol. Chem., 239 (I964) 405I.

4 C. S. Vestling, A. K. Mylkole, U. Irish and N. H. Grant, J. Biol. Chemh., 185 (1950) 789.

5 H. G. HERs, Biochim. Biophys. Acta, 8 (I952) $4 \mathbf{I} 6$.

6 H. G. Hers, Biochim. Biophys. Acta, 8 (I952) 424.

7 R. E. Parks, E. Ben-Gershom and H. A. Lardy, J. Biol. Chem., 227 (I957) 23 I.

8 C. Kuyper and J. Hoenselaars, Koninkl. Ned. Akad. Wetenschap. Proc. Ser. C, 62 (1959) 484.

9 F. PONZ AND J. M. Llinás, Nature, 197 (I963) 696.

io J. M. Llinás and F. Ponz, Rev. Españ. de Fisiol., i 8 (ig63) ioi.

т T F. J. Bat.t.ARD, Riorhem. J., 97 (1965) 365.

I 2 F. J. Ballard and I. T. Oliver, Biochem. J., 90 (1964) $26 \mathrm{I}$.

i 3 P. D. Spolter, R. C. Adelman, D. L. Di Pietro and S. Weinhouse, in G. Weber, Aduances in Enzyme Regulation, Vol. 3, Pergamon Press, Oxford, I965, p. 79.

I 4 F. A. Óckerman and II. Lundborg, Biochim. Biophys. Acta, 105 (1965) 34.

I 5 L. W. White and B. R. Landau, J. Clin. Invest., 44 (I965) I 200.

I6 R. C. Adelman, P. D. Spolter and S. Weinhouse, J. Biol. Chem., 24 I (1966) 5467.

I E. Cadenas and A. Sols, Biochim. Biophys. Acta, 42 (I96o) 490.

I8 R. C. Adelman, F. J. Ballard and S. Weinhouse, J. Biol. Chem, 242 (1967) 3360.

ig J. F. Kranhold, D. Loh and R. Curtis Morris, Jr., Science, i65 (I969) 402.

20 F. Heinz and W. Lamprecht, Comp. Biochem. Physiol., 27 (I968) 319.

2 I M. A. G. Sillero. A. Sillero and A. Sols, European J. Biochem,, io (1969) 345.

22 F. Heinz and F. Weiner, Comp. Biochem. Physiol., 3 I (I969) 283.

23 R. Adelman, H. Morris and S. Weinhouse, Cancer Res., 27 (I967) 2408.

24 N. S. Rosenzweig, F. B. Stifel, R. H. Herman and D. Zakim, Biochim. Biophys. Acta, i 70 (I968) 228.

25 R. W. Sutherland and D. W. Wolisat, J. Biol. Chem., 2 I 8 (1956) 459.

26 F. Percheron, Compt. Rend., 255 (I962) $252 \mathrm{~T}$.

27 O. H. Lowry, N. J. Rosebrough, A. L. Farr and R. J. Randall, J. Biol. Chem., I93 (I95I) 265.

28 O. Warburg and W. Christian, Biochem. $Z$., 3 Io (r942) 384.

29 J. B. Murphy ANd M. Kies, Biochim. Biophys. Acta, 45 (I960) 382.

30 R. G. Martin and B. N. Ames, J. Biol. Chem., 236 (I961) 1372.

3 I N. S. Gonzalez, S. H. Goldemberg and I. D. Algranati, Biochim. Biophys, Acta, i66 (I 968 ) 760 .

32 L. Ornstein and B. J. Davis, Ann. N.Y.Acad.Sci., I2 I (r964) 32 I.

33 O. Meyerhoff and W. Schulz, Biochem. $Z$., 289 (1936) 87.

34 H. S. Isbell and W. W. Pigman, J. Res. Natl. Bur. Std., 20 (1938) 773.

35 W. Bednarczyk and W. Marchlewski, Biochem. $Z$., 300 (I938) $4^{2}$. 
36 H. K. Schachman, in S. P. Colowick and N. O. Kaplan, Methods in Enzymology, Vol. IV, Academic Press, New York, I957, p. 32.

37 J. J. Sánchez, N. S. González and H. G. Pontis, Biochim. Biophys. Acta, 227 (1970) 79.

38 M. W. Slein, G. T. Cori and C. F. Corr, J. Biol. Chem., i 86 (I950) 773.

39 L. Ornstein and B. J. Davis, Ann. N.Y. Acad. Sci., I2 I (1964) 404.

Biochim. Biophys. Acta, 227 (197I) $67-78$ 